\title{
Swale Vincent, M.D., D.Sc., LL.D., F.R.S.C.
}

Professor Swale Vincent was born on May 24, I868, at Birmingham, where he was educated at King Edward VI Grammar School and the University, then Mason College. After graduation he went to Heidelberg to study under Kossel, and returned to become Demonstrator in Physiology in Birmingham. Here in 1896 he published his first scientific paper, which gave evidence of his interest in the physiology of the lower vertebrates; an interest he always retained. He was attracted by the work of Oliver and Schäfer upon adrenaline, and in the field of endocrinology he found his life's work. From 1897 to 1904 he held positions in University College, London, Cardiff, and Edinburgh, and at the first and last of these he was closely associated with Schäfer and his co-workers. In 1904 he was appointed Professor of Physiology in the University of Manitoba and remained there until 1920. There he did much valuable work, not only in founding and building up a department, but also in setting up a standard of enthusiasm and high achievement that made a definite impression upon the university as a whole. His services were recognised by the conferment of an honorary LL.D. He returned to England in I920 to fill the newly created chair of Physiology in Middlesex Hospital, from which he retired in 1930.

He was elected a Fellow of the Society in Igro.

$\mathrm{He}$ was an indefatigable and critical worker, and made many and noteworthy contributions to his science. Forthright in his life and speech, he did not suffer fools gladly, and would not countenance slipshod work or muddle-headedness in his pupils. To a casual acquaintance his shyness often made him appear brusque, but his friends found in him a charming companion with wide interests, and his colleagues a staunch supporter of any project that had as its object the welfare of science or of the University. His knowledge and love of music were outstanding.

He died on December 31, 1933, and is survived by his wife and two daughters.

$$
\text { C. H. O'D. }
$$

